benefits of blocking analogues of other hypothalamic polypeptide hormones, such as growth hormone releasing factor and corticotrophin releasing factor, are of enormous future interest.

\section{JONATHAN WAXMAN}

Honorary Senior Registrar,

St Bartholomew's Hospital and the Institute of Urology,

London EC1A 7BE

' McCann SM, Taleisnik S, Friedman HM. LH-Releasing activity in hypothalamic extracts. Proc Soc Exp Biol Med 1960;104:432-4.

${ }^{2}$ Schally AV, Nair RM, Carter WH. Countercurrent distribution as a tool for purification of hypothalamic hormones on a preparative scale. Anal Chem $1971 ; 43: 1527-9$.

${ }^{3}$ Monahan MW, Amoss MS, Anderson HA, Vale W. Synthetic analogues of the hypothalamic luteinizing hormone releasing factor with increased agonist or antagonist properties. Biochemistry 1973;12:4616-20.

4 Coy DH, Schally AV. Gonadotrophin releasing hormone analogues. Ann Clin Res 1978;10:139-44.

5 Tharandt L, Schulte H, Benker G, Hackenberg K, Reinwein D. Treatment of isolated gonadotropin deficiency in men with synthetic LH-RH and a more potent analogue of LH-RH. Neuroendocrinology $1977 ; 24: 195-207$.

6 Labrie F, Auclair C, Cusan L, Kelly PA, Pelletier G, Ferland L. Inhibitory effect of LH-RH and its agonists on testicular gonadotrophin receptors and spermatogenesis in the rat. Int $\mathcal{f}$ Androl 1978;2:303-18.

Belchetz PE, Plant TM, Nakai Y, Keogh EJ, Knobil E. Hypophysial response to continuous and intermittent delivery of hypothalamic gonadotropin-releasing hormone. Science 1978;202:631-3.

* Swift AD, Crighton DB. Release activity, plasma elimination and pituitary degradation of synthetic luteinizing hormone releasing hormone and its analogues. F Endocrinol 1978;77:35P.

9 Bergquist C, Nilius SJ, Bergh T, Skarin G, Wide L. Inhibitory effects on gonadotrophin secretion and gonadal function in men during chronic treatment with a potent stimulatory luteinizing hormone-releasing hormone analogue. Acta Endocrinol (Copenh) 1979;91:601-8.

${ }^{10}$ Bergquist C, Nilius SJ, Wide L. Inhibition of ovulation in women by intranasal treatment with a luteinizing hormone-releasing hormone agonist. Contraception 1979;19:497-506.

"Hsueh AJW, Erickson GF. Extrapituitary action of gonadotropinreleasing hormone: direct inhibition of ovarian steroidogenesis. Science $1979 ; 204: 854-5$.

12 Bourne GA, Regiani S, Payne AH, Marshall JC. Testicular GnRH receptors-characterization and localization on interstitial tissue. $\mathcal{f}$ Clin Endocrinol Metab 1980;51:407-9.

${ }^{13}$ Linde R, Doelle GC, Alexander N, et al. Reversible inhibition of testicular steroidogenesis and spermatogenesis by a potent gonadotropin-releasing hormone agonist in normal men. An approach toward the development of a male contraceptive. $N$ Engl f Med 1981 ;305:663-7.

14 Crowley WF Jr, Comite F, Vale W, Rivier J, Loriaux DL, Cutler GB. Therapeutic use of pituitary desensitization with a long-acting LHRH agonist. A potential new treatment for idiopathic precocious puberty. f Clin Endocrinol Metab 1980;52:370-2.

is Meldrum DR, Chang RJ, Lu J, Vale W, Rivier J, Judd HL. "Medical oophorectomy" using a long-acting GnRH agonist-a possible new approach to the treatment of endometriosis. I Clin Endocrinol Metab $1982 ; 54: 1081-3$.

16 Waxman J, Rustin MA, Perry L, Kirby J. Acne conglobata responding to buserelin, a gonadotrophin-releasing hormone analogue. $\mathrm{Br} \mathcal{J}$ Dermatol (in press.)

${ }^{17}$ Lepor H, Ross A, Walsh PC. The influence of hormonal therapy on survival of men with advanced prostatic cancer. $\mathcal{F}$ Urol 1982;128:335-40.

${ }^{18}$ Blackard CE, Byar DP, Jordan WP Jr. Orchiectomy for advanced prostatic carcinoma : a re-evaluation. Urology 1973;1:553-60.

19 Redding TW, Coy DH, Schally AV. Prostate carcinoma tumor size in rats decreases after administration of antagonists of luteinizing hormonereleasing hormone. Proc Natl Acad Sci USA 1982;79:1273-6.

"2) Tolis G, Ackman D, Apostolos S, et al. Tumour growth inhibition in patients with prostatic carcinoma treated with luteinizing hormonereleasing hormone agonists. Proc Natl Acad Sci USA 1982;79:1658-62.

$\because$ Waxman JH, Wass JAH, Hendry WF, et al. Treatment with gonadotrophin releasing hormone analogue in advanced prostatic cancer. $\mathrm{Br}$ Med F 1983;286:1309-12.

"2. Allen JM, O'Shea JP, Mashiter K, Williams G, Bloom SR. Advanced carcinoma of the prostate: treatment with a gonadotrophin releasing hormone agonist. Br Med f 1983;286:1607-9.

${ }^{23}$ Walker KJ, Nicholson RI, Turkes AO, et al. Therapeutic potential of the LHRH agonist, ICI 118630, in the treatment of advanced prostatic cancer. Lancet 1983; ii :413-5.

${ }^{24}$ Ahmed SR, Brooman PJ, Shalet SM, Howell A, Blacklock NJ, Rickards O. Treatment of advanced prostatic cancer with LHRH analogue ICI 118630: clinical response and hormonal mechanisms. Lancet 1983;ii: 415-8.

${ }^{25}$ Klijn JGM, de Jong FH. Treatment with a luteinising-hormone-releasinghormone analogue (buserelin) in premenopausal patients with metastatic breast cancer. Lancet 1982 ; i :1213-6.

\section{Patient information leaflets}

Patients are increasingly eager for information about the drugs that they are prescribed, but does knowing about the side effects of drugs stop patients taking them? This is an important question for every physician who has to prescribe for his patients. Many prescribers think that information about unwanted side effects may frighten patients and put them off taking a useful medicine, but there is insufficient evidence to be sure that this is so. Television, radio, and newspapers devote increasing space to the subject of providing information for patients about drugs, usually on the principle that "bad news" deserves several times the space that "good news" does. Unfortunately, there is no way of protecting a reader against misinformation or unbalanced views, and one result is an increasing preoccupation with "alternative medicine," as illustrated by the recent onslaught from The Times on the medical profession. ${ }^{1}$

The issue of patient information leaflets has been much debated in the United States, and the Food and Drug Administration has been considering whether it should be a requirement to issue such leaflets with all drugs obtained on prescription. ${ }^{2}$ The association of endometrial cancer with oestrogens led to a legal case in which the pharmaceutical industry and the doctors were in opposition to the Food and Drug Administration and the consumer groups, who supported a law requiring a leaflet with all tablets containing oestrogens. In the event the supporters won, but only in relation to this group of drugs. The law has now been extended, however, to cover intrauterine contraceptive devices, isoproterenol, oestrogens, progestogens, and inhalers, but moves to apply it to all drugs have been halted.

Most studies have shown that providing written material helps patients to recall information. ${ }^{34}$ Looking at the content of a leaflet providing information for patients given benzodiazepines, Fisher and colleagues showed that with care it was possible to design a leaflet that met $85 \%$ of patients' requirements. ${ }^{5}$ Traditionally the responsibility for informing the patient has rested with the prescribing physician, though there is evidence that he does not always have adequate pharmacological knowledge, is not always good at communication, and is often short of time. In these circumstances the provision of a carefully prepared leaflet, such as that described by Hermann and his colleagues, should help. ${ }^{6}$

Controlled studies of patients suffering from hypertension ${ }^{7}$ or depression ${ }^{8}$ and those taking oral contraceptives, ${ }^{9}$ have shown that information leaflets increase patients' knowledge of, and satisfaction with, their medication. George and his colleagues have confirmed this in patients in general practice receiving treatment with penicillin and non-steroidal antiinflammatory drugs. ${ }^{10}$ They also suggest that compliance improved in those patients taking penicillin but decreased in those taking non-steroidal anti-inflammatory agents. Further confusing evidence comes from two studies in which the effect of information about the potential adverse effects of oestrogens convinced over half the patients that the risk was greater than the benefit, but only a small proportion of the patients failed to take the drug. ${ }^{112}$ Myers and Calvert looked at information related to amitriptyline and found that forewarning patients of side effects did not affect the incidence of reported effects or the rate at which medication was stopped unless the advice was written down, when more side effects were reported but fewer patients stopped treatment. ${ }^{13}$ Another study from general practice on patients with cystitis reported a gain in information by patients but no influence on their compliance. ${ }^{14}$ As George 
and his colleagues say, larger studies are necessary to assess the effects of patient information leaflets. We still will not know, however, which patients will be alarmed and which reassured by a knowledge of the side effects of their treatment, nor can we predict the effect on compliance. The most we can say is that patients have a right to this information and having better informed patients usually leads to more useful discussions between doctor and patient. We should favour a more open approach but also ask for more accurate data on which to base the information that we provide.

V W M DRURY

Professor of General Practice,

University of Birmingham,

Birmingham B15 2TH

1 Anonymous. Physician heal thyself. [Editorial]. The Times 1983 Aug 12:9 (cols 1-3).

2 Ryan KJ. The FDA and the practice of medicine. $N$ Engl f Med 1977; 297:1287-8.

3 Ley P, Jain VK, Skilbeck CE. A method for decreasing patients' medication errors. Psychol Med 1976;6:599-601.

4 Winer S. Individual learning and the educator's role. Audio Visual $1979 ; 8: 117-25$.

${ }^{5}$ Fisher S, Mansbridge B, Lankford DA. Public judgements of information in a diazepam patient package insert. Arch Gen Psychiatry 1982;39: $707-11$.

${ }^{6}$ Hermann F, Herxheimer A, Lionel NDW. Package inserts for prescribed medicines: what minimum information do patients need? $\mathrm{Br} M e d \mathcal{f}$ 1978;ii:1132-5.

7 George IMSt. Patient education leaflets for hypertension: a controlled study. $7 R$ Coll Gen Pract 1983;33:508-10.

${ }^{8}$ Myers ED, Calvert EJ. The effect of forewarning on the occurrence of side-effects and discontinuance of medication in patients on amitriptyline. Br $\mathcal{F}$ Psychiatry 1973;122:461-4.

9 Morris LA, Mazis M, Gordon E. A survey of the effects of oral contraceptive patient information. $\mathcal{F} A M A 1977 ; 238: 2504-8$.

10 George CF, Waters WE, Nicholas JA. Prescription information leaflets: a pilot study in general practice. $\mathrm{Br}$ Med $\mathcal{f} 1983 ; 287: 1193-6$.

11 Udkow GP, Lasagna L, Weintraub $M$, Tamoshunas $Z$. The safety and efficacy of the estrogen patient package insert. A questionnaire study. $\mathcal{F} A M A 1979 ; 242: 536-9$.

12 Fleckstein L, Joubert P, Lawrence R, Patsner B, Mazzullo JM, Lazagna L. Oral contraceptive patient information. A questionnaire study of attitudes, knowledge, and preferred information sources. FAMA 1976; 235: $1331-6$.

${ }^{13}$ Myers ED, Calvert EJ. Knowledge of side effects and perseverance with medication. Br ₹ Psychiatry 1978;132:526-7.

14 Gauld VA. Written advice: compliance and recall. $\mathcal{F} R$ Coll Gen Pract $1981 ; 31: 553-6$.

\section{Goats' milk for infants and children}

Feeding goats' milk to babies is becoming increasingly popular and so requires more careful consideration than in the past. The main benefit claimed is that it is less allergenic than cows' milk and is a suitable substitute for babies who are allergic to the latter. Until recently goats' milk was readily available only in health food shops. Now, however, raw milk is sold in many parts of Britain and a spray dried powdered feed is being imported from New Zealand. A brochure produced by the manufacturers (Healtheries) of the powdered feed makes substantial claims": "Goats' milk is especially recommended to those who suffer from allergies to cows' milk and other staple foods and stomach ulcers. It is important for fretful babies, the elderly and those suffering from nervous indigestion, insomnia and rheumatism.... It is said to be unlike cows' milk in that it does not form excess mucus."

These general claims would be probably harmless were it not for the repeated suggestion that goats' milk is suitable for infant feeds. The claims made for its benefits in "allergy" are an echo of the current debate in medical circles and are probably no more far fetched than some professional views. Children (as opposed to babies under 6 months) with genuine or supposed food allergies are unlikely to suffer great harm if goats' milk is added to their diet and so to the list of true, possible, or imagined allergens.

Potentially much more serious is the advice that goats' milk is a suitable substitute for conventional milk feeds when babies have supposed intolerance or allergy to cows' milk protein. A pamphlet produced by the British Goat Society recommends the use of raw milk "without boiling or pasteurisation" provided that the "hygiene of production of the milk is satisfactory."2 This advice is dangerous. No untreated milk should ever be fed to young babies because of the risk of bacterial infection. By a peculiar anomaly goats' milk does not come under the government regulations that apply to most foods-for example, compulsory pasteurisation orders apply only to cows' milk.

The spray dried powder is less likely to carry any risk of infection. Unfortunately its composition is unsatisfactory as an infant formula in several ways. Its solute load is high-the content of sodium, potassium, and other electrolytes is similar to that of cows' milk. It also has a similar protein content to cows' milk, so that the production of urea and therefore the concentrations of urea in the blood and urine of babies fed goats' milk may be predicted to be of the same order as in those of babies fed unmodified cows' milk. Thus the use of goats' milk powder for infant feeding carries the same risk, predisposing to hypertonic dehydration, as does cows' milk powder. ${ }^{3-5}$ Goats' milk is deficient in folic acid and (probably) vitamin $B_{12}$. It may also be deficient in vitamins $C$ and $D$. The calcium and phosphorus ratios of cows' milk and goats' milk are similar. The risk of hypocalcaemic tetany in neonates is therefore the same for both.

Despite all the current interest goats' milk is scantily mentioned in medical publications. Since 1977 little research into its use has been reported, and certainly no evidence has appeared to support the many claims made for it, particularly not for its value to allergic infants and children. ${ }^{6-9}$ No worthwhile evidence exists to justify giving goats' milk to young children. Indeed, feeding unmodified goats' milk, whether raw or powdered, to infants has all the disadvantages of giving them unmodified cows' milk. The DHSS report Artificial Feeds for the Young Infant considers goats' milk "unsuitable," and I can only agree with this view. ${ }^{10}$

If, however, despite the lack of nutritional or medical evidence of benefit parents choose to feed their babies with goats' milk they may avoid the main hazards by using the following guidelines. Firstly, raw goats' milk should be pasteurised or boiled. Animals should have been tested for both tuberculosis and brucellosis. The present loophole in the laws on milk hygiene should be closed without delay in view of the apparent growing popularity of goats' milk. Secondly, because of its high solute content, goats' milk should be diluted to threequarter strength. This decreases its energy content and some form of carbohydrate such as sucrose should be added. Undiluted goats' milk is unsafe for babies under 6 months of age, and even diluted is not ideal. Thirdly, supplements of folic acid and vitamin $B_{12}$ are needed in addition to the supplement of vitamins $\mathrm{A}, \mathrm{C}$, and D given to babies fed cows' milk formulas.

Should goats' milk ever be recommended on medical grounds the ideal would be a prepared infant formula meeting the requirements of the DHSS report. ${ }^{10}$ No such formula is currently available, but in view of the evidence it is questionable whether resources should be used to produce one.

Finally, any goats' milk product should have a stated shelf 